\title{
Effect of raw materials nomenclature and their temperature upon safety and quality parameters of mechanically separated poultry meat
}

\author{
Georgiy Yeresko1, Galina Cherednichenko², \\ Svitlana Bondar ${ }^{1}$, Sergii Verbytskyi ${ }^{1}$
}

\section{1 - Institute of Food Resource of National Academy of Agrarian Sciences of Ukraine, Kyiv} 2 - National University of Food Technologies, Kyiv, Ukraine

Keywords:

Meat

Bird

Bone

Temperature

Safety

Article history:

Received

15.04.2017

Received in

revised form

19.06.2017

Accepted

05.09.2017

\section{Corresponding \\ author:}

Svitlana Bondar

E-mail:

Svetabondar1989@ gmail.com

DOI:

$10.24263 / 2310-$

$1008-2017-5-1-3$

\section{Abstract}

Introduction. The research was conducted to determine the influence of technological factors and basic properties of different types of raw materials on the determinants of quality and food safety of poultry meat mechanically separated.

Materials and methods. To fulfill the research most practical and widely spread raw materials for manufacturing mechanically separated poultry meat were used, namely these: whole carcasses of broilers and hens, hen necks and broiler backs. Temperature ranged from minus $4{ }^{\circ} \mathrm{C}$ to $6{ }^{\circ} \mathrm{C}$. Research was fulfilled using screw type press-separator «Lima» and band type press-separator «Baader».

Results and discussion. A certain range of the most proper temperature parameters corresponds to each of the types of raw materials studied thus enabling producing mechanically separated poultry meat of the safe content of bone inclusions by significantly high output of end product. During the hard separation using screw separator machines the said range is from $0{ }^{\circ} \mathrm{C}$ to $2{ }^{\circ} \mathrm{C}$ for almost all the types of the raw materials processed. Decline in bone inclusions content is detected from the temperature threshold of minus $2{ }^{\circ} \mathrm{C}$. In some way lower product output is offset with the quality of the staff obtained namely the content of bone inclusions. The most proper range for broilers and hen necks is from $4{ }^{\circ} \mathrm{C}$ to $6{ }^{\circ} \mathrm{C}$. Rather a similar effect is found for soft separation with the use of band machines. The surfacefrozen raw materials are usually known not to be processed with separators of the said type - mainly, because of rapid wear of the pressing band of the separation unit and lower, comparing to screw separator machines, pressure effecting the raw materials. When raw materials are surface-frozen by minus $2{ }^{\circ} \mathrm{C}$ and are to be processed with the use of band separators, the said raw materials shall be preliminary ground with the use of meat grinders (meat wolves) equipped with the plates with big diameter orifices.

In average by $9-10 \%$ lower output of mechanically separated poultry meat is characteristic for soft separation comparing to hard separation, while the average content of bone inclusions in the case of hard separation is by $40 \%$ higher. The most proper, considering technology and food safety issues, temperature range of raw materials is from $2{ }^{\circ} \mathrm{C}$ to $6{ }^{\circ} \mathrm{C}$. The use of raw materials their temperature being lower than minus $2{ }^{\circ} \mathrm{C}$ is not applicable. The said is especially true for hen necks, as with the decline in temperature the raise in bone inclusions content in end product is drastic.

Conclusion. The research making it possible to obtain mechanically separated poultry meat of minimal bone inclusions content while output values of end products being significant. 


\section{Introduction}

A significant part of meat protein raw materials in the formulations of the said foods belongs to such poultry raw meats as ground meat after manual deboning and meat of mechanical deboning. More significant part of mechanically deboned meat is often considered to be a beneficial factor for enriching a product with fat, vitamins, mineral substances etc. [1]. It is proven [2], that the nutritional value of poultry meat (namely broiler chickens and turkeys meats) being mechanically deboned is almost equal to the values of the said parameters measured in canned sardines, anchovy and mackerel overwhelming the values measured in plant oils and beef products, while PER (Protein Efficiency Ratio) value in mechanically deboned poultry meat was greater than PER values measured in all the foods mentioned above. However the significant content of bone inclusions confines the use of mechanically deboned poultry meat these inclusions being difficult for detection and proper assessment [3,4]. A number of studies have been held to determine content of this raw food, namely quality parameters, proteins, lipids and minerals content, bone rests together with stability of proteins and lipids, the presence of pathogen and other microorganisms. Mechanically deboned poultry meat has proven its nutritional and functional traits while being safe for human life and health. The mechanical deboning technology allows preserving useful minerals, lipids and proteins, so that the product obtained as a result of fulfillment of the said technological process can be used for formulating a range of meat foods $[5,6]$. At the same time, the mechanical process of removing meat from the bone causes cell breakage, protein denaturation (with deterioration of mechanical properties) and an increase in lipids and free heme groups, which implies several disadvantages, such as color, flavor, palatability (attenuation of characteristic taste) and microbial load, making mechanically separated poultry meat a highly perishable raw material [7]. When the effect of adding chicken breast $(5,15$ or $25 \%)$ or mechanically deboned chicken meat $(5,15,25$ or $35 \%)$ on quality characteristics of emulsion-type sausage was evaluated [8], it was determined that addition of chicken breast sausages caused increased moisture and protein content (\%), but decreased fat content of the sausages. Addition of mechanically deboned chicken meat to sausages caused decrease in the moisture and protein content $(\%)$, but increase in the fat content $(\%)$ of the sausages. Addition of chicken breast to sausages caused raise in $\mathrm{P}, \mathrm{Na}$ and $\mathrm{Cu}$ contents. Addition of mechanically deboned chicken meat sausages caused increase in $\mathrm{Ca}$ and $\mathrm{Fe}$ contents. The addition of chicken breast sausages increased the hardness, springiness, gumminess and chewiness values, but the addition of mechanically deboned chicken meat to sausages decreased the hardness, springiness, gumminess and chewiness values, so that addition of mechanically deboned chicken meat was the best choice concerning the quality of the sausages.

\section{Materials and methods}

To fulfill the research, the most practical and widely spread raw materials for manufacturing mechanically separated poultry meat were used, namely these: whole carcasses of broilers and hens, hen necks and broiler backs. Temperature ranged from minus $4{ }^{\circ} \mathrm{C}$ to $6{ }^{\circ} \mathrm{C}$.

Research was fulfilled using screw type press-separator «Lima» and band type pressseparator «Baader». 
Temperature of the assayed ground meats was determined with the digital thermometer «Checktemp» $\mathrm{HI} 98509$. Determination range is from -50 to $150{ }^{\circ} \mathrm{C}$. Resolution is $0.1{ }^{\circ} \mathrm{C}$. Accuracy is $\pm 0.3{ }^{\circ} \mathrm{C}$ (within temperature range from -20 to $90{ }^{\circ} \mathrm{C}$ ).

Weight of samples was determined with the use of digital laboratory scale «OHAUS RU 313». Determination range is from 0 to $310 \mathrm{~g}$. Accuracy of measurement $\pm 0.001 \mathrm{~g}$.

Parameters of raw materials and mechanically separated poultry meat were determined with the use of following methods.

Content (by mass) of bone inclusions in mechanically separated poultry meat was determined with the use of the specially developed method, implying separation of the said particles from other components of the product. Muscle, connective and adipose tissues of a sample are removed by boiling in alkaline solution. Not dissolved particles of the probe are separated from bone inclusions by means of concentrated solution of zinc chloride.

Measurement of weight of bone inclusions is done after removing the excess zinc chloride solution and drying in air oven.

Content of bone inclusion (by mass) is calculated with taking probe weight into account. The range of bone inclusion (by mass) content by gravimetric method is from $0.05 \%$ to $1.5 \%$.

The procedure of bone inclusion (by mass) content determination is following.

Potassium hydroxide solution (mass fraction $2 \%$ ) shall be prepared by dissolving a $(20.0 \pm 0.5) \mathrm{g}$ probe of potassium hydroxide in $980 \mathrm{~cm}^{3}$ of distilled water.

Concentrated solution of zinc chloride shall be prepared. For the purpose saturated solution of zinc chloride shall preliminary be prepared - a probe of zinc chloride of weight of (280-300) $\mathrm{g}$ shall be dissolved in $100 \mathrm{~cm}^{3}$ of distilled water. For a probe of a sample analyzed about $70 \mathrm{~cm}^{3}$ of concentrated solution of density from $1.65 \mathrm{~g} / \mathrm{cm}^{3}$ to $1.8 \mathrm{~g} / \mathrm{cm}^{3}$ is necessary. Incinerated calcium chloride is placed at the bottom of clean and dry desiccators. A sample of mechanically separated poultry meat shall be comminuted to pasty body and refrigerated by temperature not exceeding $4{ }^{\circ} \mathrm{C}$.

A $(50.00 \pm 0.05) \mathrm{g}$ probe of sample is weighed in a $250 \mathrm{~cm}^{3}$ beaker, then $100 \mathrm{~cm}^{3}$ of water solution of potassium hydroxide of mass fraction $2 \%$ shall be added and mixed thoroughly. The beaker with the sample probe shall be placed on water-bath its temperature not being less than $80^{\circ} \mathrm{C}$. The content of beaker shall be stirred occasionally from $1 \mathrm{~h}$ to $1.5 \mathrm{~h}$ to dissolve fragments of muscle tissue till a layer of not dissolved connective and adipose tissues is formed at the surface of the solution.

The sample shall be removed from water-bath and let settle for about $2 \mathrm{~min}$. The upper layer of solution with the fragments of not dissolved connective and melted adipose tissues shall be decanted with care. After decanting the side walls of the beakers shall be wiped with a cotton or gauze wad rinsed with hot water in the case when the rests of adipose have adhered to. The wad shall be discharged. A portion of $2 \%$ potassium hydroxide solution shall be added to the rest of the sample in such a way that the level of solution in beaker was about the same as the solution level before decanting, the solution shall be placed on water-bath again. Adding of potassium hydroxide solution, heating, retention and decanting shall be fulfilled repeatedly before the full dissolving of muscle tissue and removing of adipose and connective tissues. Bone inclusions and other not dissolved particles, separated from the sample, settle at the bottom of the beaker.

The potassium hydroxide solution with settled bone inclusions and other not dissolved particles is decanted with care to prevent from their settling at the walls of the beaker. Then bone inclusions and other not dissolved particles shall be washed in beaker with distilled water 3-4 times by portions of $100-150 \mathrm{~cm}^{3}$. 
After washing bone inclusions and other not dissolved particles shall be carried to dried and weighed to constant mass beakers by rinsing with distilled water, the result of weight measurement shall be recorded with the accuracy of $0.001 \mathrm{~g}$. Then bone inclusions and other not dissolved particles shall be separated with the use of concentrated zinc chloride solution, for the purpose the precipitate with bone inclusions and other not dissolved particles is carried to the beaker by rinsing. The rest of the precipitate is diluted with concentrated zinc chloride solution to fill about $3 / 4$ of the beaker volume. The content of the beaker is mixed by a glass stick and let settle for 1-2 min. Not dissolved particles float at the surface of concentrated zinc chloride solution, as the density of the said solution is higher than the density of not dissolved particles but lower than the density of bone inclusions. The concentrated zinc chloride solution together with not dissolved particles shall be decanted through a strainer to a separate glass in such a way that bone inclusions are still at the bottom of the beaker. When some of not dissolved and not yet separated from the bone inclusions particles are still in the precipitate, the separation process fulfill repeatedly with the use of concentrated zinc chloride solution of higher density before the full separation of bone inclusions from other not dissolved particles. Thus separated bone inclusions are washed by distilled water to remove zinc chloride solution completely. During the washing a cloudy solution of light gray color and heterogeneous density is formed, the sludge gradually precipitates at the bottom of the beaker and gets white. The most light-weighted bone inclusions retain in the solution so they can be decanted with the solution when washed without care. To prevent this, the content of the beaker shall be mixed with a glass stick to let the bone inclusions precipitate, then the upper transparent layer of the solution shall be decanted with care. By gradual adding and decanting distilled water, complete washing out of zinc chloride shall be achieved. The washing process with distilled water is considered to be complete when the liquid above the bone inclusions becomes transparent.

Beakers with completely separated, washed bone inclusions shall be dried by the temperature $(103 \pm 2){ }^{\circ} \mathrm{C}$ during $1 \mathrm{~h}$, inserted from the air oven, sealed and placed to desiccator completely filled with the incinerated calcium chloride and cool to the ambient temperature. The duplicate sample shall be prepared in similar way.

After cooling to ambient temperature in desiccator the beakers shall be weighed on the balance. Results shall be recorded with the accuracy of $0.001 \mathrm{~g}$. The beakers shall be placed into drying oven again, allowed to stay for $30 \mathrm{~min}$, cooled and weighed again. When decrease of weight from the first to the second weighing does not exceed $0.005 \mathrm{~g}$, drying shall be finished, but when decrease of weight exceeds $0.005 \mathrm{~g}$, the beakers shall be placed into drying oven again. Drying periods of $30 \mathrm{~min}$ shall be successively repeated till difference of weight between successive dryings does not exceed $0.005 \mathrm{~g}$. The results of weighing shall be recorded to three decimal places.

Results of determination of bone inclusions content (by mass) in mechanically separated poultry meat $\omega, \%$, in $i$ parallel is calculated by formula:

$$
\omega_{i}=\frac{\left(m_{i 1}-m_{i 2}\right)}{m_{i}} \times 100,
$$

where $m_{i 1}$ - weight of a beaker with bone inclusions, g; $m_{i 2}$ - weight of a beaker, g; $m_{i}-$ weight of test portion, $\mathrm{g} ; i$ - number of a parallel sample $(i=1,2)$.

Arithmetic mean of the results of two parallel determinations is recorded as the end result of measurements of bone inclusions content in mechanically separated poultry meat when the results of repeatability control are positive. 
Outcome of mechanically separated poultry meat is determined as the relation of the mass of meat processed with the use of an appliance to the mass of the raw materials used for processing, $\%$.

$$
X=100 \frac{\left(m_{1}-m_{2}\right)}{m},
$$

where $A$ - mass of meat processed with the use of an appliance, $\mathrm{g} ; C$ - the mass of the raw materials used for processing, g;

Statistical analysis of the results obtained was fulfilled on the base of calculation of arithmetic mean values and quadratic mean. All the experimental data are the results of 5 parallel determinations.

\section{Results and discussion}

Important parameters of mechanically separated poultry meat are the linear dimensions of its particles and fractional content of bone inclusions. The said parameters are influenced by machinery design and wear degree of working surfaces of separating units [9]. The fractional content of bone inclusions and their linear dimensions are sufficiently influenced by the diameter of filter orifices of a separating unit. With the decrease of orifices the dimensions of bone inclusions also decrease and the part of fine fraction increases. By the equal perforation dimensions, product safety level is sufficiently influenced by pressure determining the output of the product. Thus, very fine bone inclusions are characteristic for the perforation of $0.8 \mathrm{~mm}$ orifices, moreover, with the decrease of output the part of fine inclusions increases. With the decrease of output, part of fine fraction decreases and part of big fraction increases. Так, when output exceeds $68.7 \%$ rather big bone inclusions of 526.4 $\mu \mathrm{m}$ dimensions can be observed in the staff processed, however the part of the said inclusions is not sufficient counting up to $0.27 \%$. When a separating cylinder of $1.0 \mathrm{~mm}$ orifices is used, the part of fine fraction with dimensions up to $300 \mu \mathrm{m}$ decreases, but the quantity of bone fragments with bigger dimensions increases. Such pattern is also true for perforation orifices with $1.1 \mathrm{~mm}$ diameter, but the part of 300.1 to $500 \mu \mathrm{m}$ fraction increases from 0.3 to $5.75 \%$. When $1.2 \mathrm{~mm}$ perforation is used, the part of the fraction with bone fragments dimensions from 300.1 to $500 \mu \mathrm{m}$ decreases 3.8 times, but bone inclusions of $576.9 \mu \mathrm{m}$ dimension can already be observed in the quantity of $1.5 \%$. When a cylinder of $1.4 \mathrm{~mm}$ separation orifices is used, the part of 300.1 to $500 \mu \mathrm{m}$ bone inclusion increases from 0.99 to $2.63 \%$ with simultaneous increase of particles dimensions within the fraction from 350.9 to $401.4 \mu \mathrm{m}$. To this, bone inclusions can be detected in mechanically separated poultry meat: those of $621 \mu \mathrm{m}$ in the quantity of $2.64 \%$, and those of the dimensions from 954.1 to $1053.0 \mu \mathrm{m}$ in the quantity from 0.5 to $2.26 \%$ [10].

The manufacturing process of mechanically separated poultry meat can be fulfilled with the use of high pressure. Such technological solution is simpler when its technical performance is considered, but the structure of the staff obtained is destroyed its slime profile being not proper from the technologists' point of view. However, low pressure allows obtaining the profile characteristic for the ground meats of manual deboning, but high output of the produce cannot be achieved. More valuable parts of carcasses, namely filets, legs and drumsticks are used in great amounts, correspondingly the amounts of the raw materials available for manufacturing mechanically separated poultry meat also rise, its range of possible use in meat industry becoming wider [11]. However, the terminology used to determine objects and processes connected with mechanical deboning of poultry 
carcasses and their pats cannot be considered to have become of common use. According to [12], the term «mechanically separated meat» is used, this defining the product, obtained by removing meat from bones or poultry carcasses with the use of mechanical tools, when muscle fibers are destroyed or modified in some other way. The authors of [12] classify mechanically separated meat obtained with low pressure (type I), and with high pressure thus causing loss or modification of muscle fibers (type II). In the first case meat staff is obtained with the use of the methods not leading the modification of the raw materials used. Mechanically separated meat obtained in any other way than that specified for type I pertains to type II. Other authors [13-16] noticing significant dependence of quality parameters of mechanically separated poultry meat upon the separation method applied use the term «hard separation» for the separation process with high pressure and the term «soft separation» for the separation process with low pressure. Processing with the latter method not modifying the structure of raw materials can be fulfilled, for example, by the separators of «Baader» company [13-16]. According to [17], up to $77 \%$ of all mechanically separated poultry meats produced in EU are separated with high pressure. Market costs of such staff are from 0.3 до 0.6 Euro $/ \mathrm{kg}$, however the meat staffs of the soft separation are from 0.6 to 1.5 Euro/kg. Mechanically separated poultry meat obtained with low pressure not only possesses such trait as not destroyed structure, it also contains less calcium and phosphorus, its characteristic microbial contamination is also lower. That is why possibility and necessity of introducing a new term for such raw materials is considered, this differing from «mechanically deboned poultry meat» $[13-15,17]$.

To carry out the technological process of mechanical separation of poultry meat piston, screw and band methods are the most practical to remove muscle tissue from bones. The diversity of the technical solutions is certain not to be confined neither with three above mentioned technological schemes nor with some wider nomenclature presented at Figure 1. Screw presses are very practical the principle of their action basing at the pressing of raw materials with high pressure in the orifices of perforation. In the working areas of these machines muscle tissue is separated with the flights of working screw and edges of orifices thus enabling separation of raw material into fluid fraction (muscle tissue) and hard fraction (bone rests). From the other side, the action of the mechanical appliances of the said type causes excessive heating of the staff processed, this, in its turn, being the reason for the significant worsening of its technological properties. Sensorial properties are not proper either as the staff obtained has the smack of burnt bones. According to the second, of the three mentioned, technological scheme piston separators work, these belonging to batch action machines and equipped with powerful hydraulic drive. Meat and bone raw materials are loaded into the hopper and pressed with the use of piston, the pieces of muscle tissue being forced through the orifices of perforated cylinder and hard fraction being compressed and removed when a cycle is finished. Force intensive action of piston type appliances may cause smashing the muscle tissue and modifying of its structure, thus being the reason of undesirable paste like profile of the staff obtained. A gentler mode, considering meat structure, is the mode of the operation of the band separating machines, this mode is often called soft as the muscle tissue being processed with the use of the said appliances undergoes short time depression only thus promoting production of ground meat like staff without excessive heating. Band separation after the first manufacturer of such equipment is often called «baadering». The principal structural member of the machines of the said type is endless band made of nonmetal material. The surface of the band has adhesive properties promoting soft removing of meat from bones, meat staff being led out of working area of machine through perforated drum. For band separators uniform content of bone inclusions is characteristic, the most part of them, about $85 \%$ of overall number, pertaining fine 
fraction - up to $500 \mu \mathrm{m}$ and middle size fraction - from $500 \mu \mathrm{m}$ to $750 \mu \mathrm{m}$, these distributed almost in equal parts - by $40-45 \%$ each. The rest (about $15-20 \%$ ) is the fraction of big bone inclusions with the dimensions exceeding $750 \mu \mathrm{m}$. [18-20].
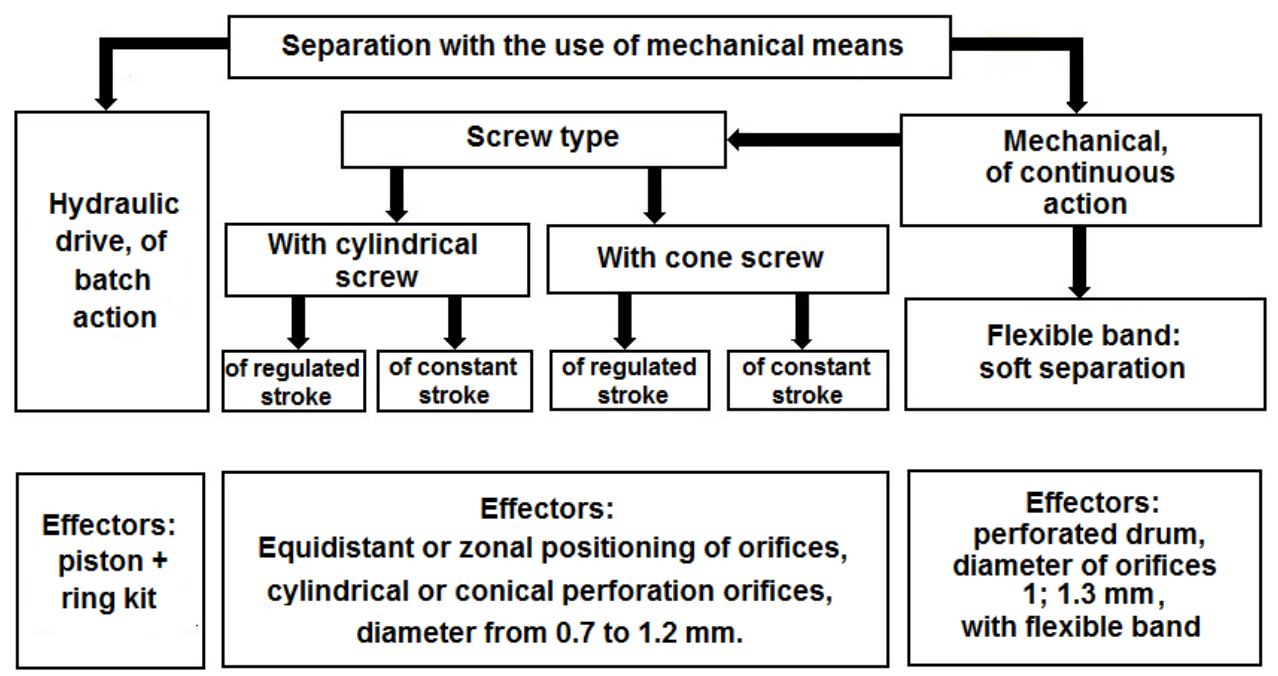

Figure 1. Principal design schemes to separate poultry meat from bones with the use of mechanical means

Therefore, current equipment for «soft» separating of meat and bone staff allows obtaining of high quality mechanically separated poultry meat with necessity to apply labor-intensive manual operations, foremost desinewing - separating of connective tissue, tendons, skin, small bones etc. An important raw material resource to produce mechanically separated poultry meat is also a number of low value muscle cuts. «Soft» separation equipment allows processing of meat and bone raw materials with the output of meat staff from 85 to $95 \%$, enhancing of processing quality and obtaining, as a result, granular ground meat its destruction rate and waterholding capacity being optimal to manufacture high grade pâté products. The separated hard particles can be used to manufacture pâté products of lower price level thus providing their availability to the consumers of low income.

Raw materials to produce mechanically separated poultry meat shall have certain technological requirements, these guaranteeing economically viable outputs of high quality product and its successive storing. The principal technological parameter in the production of mechanically separated poultry meat is the temperature of raw materials to be processed. In the process of mechanical separation of whole poultry carcasses, halves together with parts of carcasses abounding with soft tissues (both muscle and adipose) a separation appliance operates in a normal regime when the temperature of raw materials to be processed is from minus $2{ }^{\circ} \mathrm{C}$ to minus $4{ }^{\circ} \mathrm{C}$. By lower temperature values the load upon grinder (bone crusher) and deboning machine increases, the wear intensifies, the quality of separation of meat and bone fractions worsens, thus making the output of muscle fraction lower. When the temperature o raw materials is higher than minus $2{ }^{\circ} \mathrm{C}$, especially when the temperature is no less than $0{ }^{\circ} \mathrm{C}$, by complete defrosting of meat technical and economical parameters of the deboning process sufficiently decrease. However the most part of the machines used for mechanical separation of poultry meat are intended to process 
the chilled raw materials but not the frozen ones. There is information yet, that modified separators are being developed these also allowing processing frozen meats and thus obtaining the product of perfect texture, longer shelf life and lower bacterial contamination [21].

Results of the research of the effect of raw materials nomenclature and their temperature upon the output of the poultry meat obtained by hard and soft separation and bone inclusions content of the said meat are shown in Table 1.

Table 1

Effect of raw materials nomenclature and their temperature upon the output of the poultry meat obtained by hard and soft separation and bone inclusions content

\begin{tabular}{|c|c|c|c|c|c|}
\hline \multirow{3}{*}{$\begin{array}{c}\text { Raw } \\
\text { material } \\
\text { used }\end{array}$} & \multirow{3}{*}{$\begin{array}{c}\text { Temperature, } \\
{ }^{\circ} \mathrm{C}\end{array}$} & \multicolumn{4}{|c|}{ Separation mode } \\
\hline & & \multicolumn{2}{|c|}{ Hard (screw separator) } & \multicolumn{2}{|c|}{ Soft (band separator) } \\
\hline & & Output, $\%$ & $\begin{array}{c}\text { Bone } \\
\text { inclusions } \\
\text { content, \% }\end{array}$ & Output, $\%$ & $\begin{array}{c}\text { Bone } \\
\text { inclusions } \\
\text { content, } \%\end{array}$ \\
\hline \multirow{7}{*}{$\begin{array}{c}\text { Carcasses of } \\
\text { broiler } \\
\text { chickens }\end{array}$} & -4 & 80.1 & 0.36 & & \\
\hline & -3 & 78.4 & 0.33 & & \\
\hline & -2 & 75.3 & 0.22 & 64.1 & 0.18 \\
\hline & from 0 to 2 & 75.7 & 0.09 & 73.4 & 0.08 \\
\hline & from 3 to 4 & 80.3 & 0.25 & 57.2 & 0.03 \\
\hline & 4 & 76.2 & 0.28 & 72.2 & 0.10 \\
\hline & 6 & 75.3 & 0.29 & 74.7 & 0.14 \\
\hline \multirow{7}{*}{$\begin{array}{l}\text { Backs of } \\
\text { broiler } \\
\text { chickens }\end{array}$} & -4 & 69.3 & 0.30 & & \\
\hline & -3 & 65.9 & 0.20 & & \\
\hline & -2 & 64.4 & 0.15 & 59.8 & 0.15 \\
\hline & from 0 to 2 & 60.2 & 0.08 & 60.2 & 0.10 \\
\hline & from 3 to 4 & 69.1 & 0.13 & 60.1 & 0.14 \\
\hline & 4 & 69.5 & 0.25 & 59.5 & 0.16 \\
\hline & 6 & 68.6 & 0.30 & 60.6 & 0.16 \\
\hline \multirow{7}{*}{$\begin{array}{c}\text { Carcasses of } \\
\text { hens }\end{array}$} & -4 & 77.2 & 0.35 & & \\
\hline & -3 & 76.9 & 0.34 & & \\
\hline & -2 & 76.4 & 0.21 & 68.4 & 0.15 \\
\hline & from 0 to 2 & 74.7 & 0.10 & 65.7 & 0.09 \\
\hline & from 3 to 4 & 76,3 & 0.11 & 66.3 & 0.10 \\
\hline & 4 & 75.2 & 0.23 & 68.2 & 0.13 \\
\hline & 6 & 72.4 & 0.26 & 68.3 & 0.15 \\
\hline \multirow{7}{*}{$\begin{array}{l}\text { Necks of } \\
\text { hens }\end{array}$} & -4 & 67.7 & 0.34 & & \\
\hline & -3 & 68.3 & 0.31 & & \\
\hline & -2 & 71.4 & 0.12 & 60.4 & 0.36 \\
\hline & from 0 to 2 & 70.2 & 0.10 & 60.2 & 0.22 \\
\hline & from 3 to 4 & 71.0 & 0.20 & 58.3 & 0.17 \\
\hline & 4 & 71.4 & 0.23 & 61.4 & 0.18 \\
\hline & 6 & 73.8 & 0.22 & 61.8 & 0.19 \\
\hline
\end{tabular}


Analyzing of the table data allows drawing the conclusion, that a certain range of the most proper temperature parameters corresponds to each of the types of raw materials studied thus enabling to produce mechanically separated poultry meat of the safe content of bone inclusions by significantly high output of end product. During the hard separation using screw separator machines, the said range is from $0{ }^{\circ} \mathrm{C}$ to $2{ }^{\circ} \mathrm{C}$ for almost all the types of the raw materials processed. Decline in bone inclusions content is detected from the temperature threshold of minus $2{ }^{\circ} \mathrm{C}$. In some way lower product output is offset with the quality of the staff obtained - namely by its content of bone inclusions. The most proper range for broiler and hen necks is from $4{ }^{\circ} \mathrm{C}$ to $6{ }^{\circ} \mathrm{C}$. Rather a similar effect is found for soft separation with the use of band machines. The surface-frozen raw materials are usually known not to be processed with separators of the said type - mainly, because of rapid wear of the pressing band of separation unit and lower, comparing to screw separator machines, pressure effecting the raw materials. When raw materials are surface-frozen by minus $2{ }^{\circ} \mathrm{C}$ and are to be processed with the use of band separators, the said raw materials shall be preliminary ground with the use meat grinders (meat wolves) equipped with the plates with big diameter orifices.

Assessment of the data adduced within the table makes a conclusion possible, that lower (in average by $9-10 \%$ ) output of mechanically separated poultry meat is characteristic for soft separation comparing to hard separation, while the average content of bone inclusions in the case of hard separation is by $40 \%$ higher. The most proper, considering technology and food safety issues, temperature range of raw materials is from 2 ${ }^{\circ} \mathrm{C}$ to $6{ }^{\circ} \mathrm{C}$. The use of raw materials their temperature being lower than minus $2{ }^{\circ} \mathrm{C}$ is not applicable. The above said is especially true for hen necks, as with the decline in temperature the raise in bone inclusions content in end product is drastic. The latter regime is less proper considering the longevity of the separating equipment used to perform the process its effectors undergoing significant wear.

\section{Conclusion}

When producing mechanically separated poultry meat, the principal technological parameter is the temperature of raw materials to be processed. The said implies raw materials with different values of meat/bone index. For the raw materials with low values of meat/bone index, e.g. broiler backs and hen necks, the most proper, considering output of end product and its content of bone inclusions, temperature range is higher temperatures area, namely from $2{ }^{\circ} \mathrm{C}$ to $6{ }^{\circ} \mathrm{C}$. For the raw materials with higher meat/bone index the technologically proper temperature range is from minus $2{ }^{\circ} \mathrm{C}$ to plus $2{ }^{\circ} \mathrm{C}$, complying with the said range making it possible to obtain mechanically separated poultry meat of minimal bone inclusions content while output values of end products being significant.

\section{References}

1. Bondar S.V., Verbytskyi, S.B. \& Voitsekhivska L.U. (2016), Evaluating prospects to use mechanically separated poultry meats as a raw material for production of pâtés. Materials of All-Ukrainian scientific and practical conference "Scienific achievements of the youth for solving the problems of agroindustrial complex", Institute of Agricultural Production of Polissya, Zhytomyr, pp. 52-55. 
2. Babji A. S., Fatimah S., Abolhassani Y. \& Ghassem M. (2010), Nutritional quality and properties of protein and lipid in processed meat products - a perspective, International Food Research Journal, 17(1), pp. 35-44.

3. Marco Antonio Trindade, Pedro Eduardo de Felício, Carmen Josefina Contreras Castillo (2004), Mechanically separated meat of broiler breeder and white layer spent hens, Sci. Agric., 61(2), pp. 234-239.

4. Branscheid W., Judas M., Höreth R. (2009), The morphological detection of bone and cartilage particles in mechanically separated meat, Journal Meat Science, 81(1), pp. $46-50$.

5. Serdaroğlu M., Yıldız Turp G., Bağdatlığlu N. (2005), Effect off deboning methods on chemical composition and some properties of beef and turkey meat, Turkish Journal of Veterinary and Animal Sciences, 29, pp.707-802.

6. Madeira M.V. (2014), Avaliação da qualidade da carne de aves separada mecanicamente. Doctoral dissertation, Instituto Politécnico de Santarém.

7. Pereira A.G.T., Ramos E.M., Teixeira J.T., Cardoso G.P., Ramos A.D.L.S., Fontes P.R. (2011), Effects of the addition of mechanically deboned poultry meat and collagen fibers on quality characteristics of frankfurter-type sausages, Meat science, 89(4), pp. 519-525.

8. Hyun-Woo Seo, Pil-Nam Seong, Yun-Seok Kim, Soo-Hyun Cho, Sung-Sil Moon, Beom-Young Park, Jin-Hyoung Kim (2017), Effects of quality characteristics of the emulsions-type sausage of added chicken breast or mechanically deboned chicken meat, Journal of Agriculture and Life Science, 51(1), pp. 223-232.

9. Abaldova V.A., Ovcharenko V.I. (1999), Effect of separating unit design upon the process of mechanical deboning of poultry and parameters of the process, Poultry \& Its Processing, 3, pp. 28-31.

10. Abaldova V.A. \& Ovcharenko V.I. (2013) Separating unit holes diameter influence on mechanically deboned meat safety, Poultry \& Chicken Products, 3, pp. 66-68.

11. Danyluk B., Bilska A., Kowalski R. \& Danyluk M. (2016), Evaluation of selected quality characteristics of fine ground sausages of frankfurter type containing MSPM, Nauka Przyroda Technologie, 10(4), p. 42.

12. James C., Purnell G., James S. J. (2013), Description of the Processes used in the UK to Manufacture MSM and Former DSM Meat Products from Poultry and Pork and an Initial Assessment of Microbiological Risk, p. 39.

13. Cegielka A., Kuczynska N., Pietrzak D. (2014), Zastąpienie surowca wieprzowowołowego w kiełbasach homogenizowanych przez mięso drobiowe oddzielone mechanicznie, uzyskane po separacji wysoko- i niskociśnieniowej, Żywność Nauka Technologia Jakość, 21(3), pp. 123-135.

14. Henckela P., Vybergb M., Thodec S., Hermansen S. (2004), Assessing the quality of mechanically and manually recovered chicken meat, LWT-Food Sci. Technol., 37, pp. 593-601.

15. Kubiak M.S. (2007), Barwa mięsa indyczego pozyskanego podczas separacji miękkiej na urządzeniu SEPAMATIC 1200 ST, Gosp. Mięs., 59(3), pp.42-43.

16. Michalski M. (2009), Zawartość wapnia w mięsie oddzielonym mechanicznie metodą tradycyjną (ciśnieniową) i techniką nieniszczącą struktury kości, Rocz. Inst. Przem. Mięs. Ttuszcz., 47(1), pp. 77-82.

17. Makała H. (2012), Właściwości i wykorzystanie mięsa mechanicznie odkostnionego wybrane zagadnienia, Gosp. Mięs., 64(4), pp. 12-16. 
18. Bondar S.V., Verbytskyi S.B., Okhrimenko Y.I. and Klishchova T.Y. (2015), Results of comparative research of different poultry meats separated with the use of mechanical means, Food Resources, 5, pp. 64-71.

19. Nagy J., Lenhardt L., Korimová L., Dičáková Z., Popelka P., Pipová M. \& Tomková I. (2007), Comparison of the quality of mechanically deboned poultry meat after different methods of separation, Meso, 9(2), pp. 92-95.

20. Bibwe B.R., Hiregoudar S., Nidoni U.R. \& Shrestha M.B. (2013), Development of meat-bone separator for small scale fish processing, Journal of Food Science and Technology, 50(4), pp. 763-769.

21. Bondar S.V., Voitsekhivska L.U., Verbytskyi S.B., Okhrimenko Y.I., Klishchova T.Y., Sokolova S.Y. (2016), Study of dependence of content of bone inclusions in mechanically separated poultry from temperature and type of raw material, Food Resources, 8, pp. 86-92. 